\title{
Explorative Study on Henry Luce's Idea of Journal Editing
}

\author{
Yuqing Xiao \\ Journalism Schools, Xihua Normal University, Nanchong, China \\ Email:674335141@qq.com
}

Received 2 November 2015; accepted 29 November 2015; published 2 December 2015

Copyright (C) 2015 by author and Scientific Research Publishing Inc.

This work is licensed under the Creative Commons Attribution International License (CC BY). http://creativecommons.org/licenses/by/4.0/

(c) (†) Open Access

\begin{abstract}
As the founder of TIME, FORTUNE and LIFE, Henry Luce changed people's way of news consumption and their view of the world. The idea concept of "news magazine" initiated by Luce is very popular among the middle class. His idea of journal editing has influenced a large number of followers. This paper sorts and studies Henry Luc's idea of journal editing in order to inspire editors of modern newspapers and periodicals.
\end{abstract}

Keywords

Henry Luce, Newsweekly, Journal Editing Idea

\section{Introduction}

Every industry has its legend. Luce is a legendary figure in modern media industry. As the founder of TIME, FORTUNE and LIFE, Hency Luce has changed the way how people consume news and understand the world. TIME shows respect for current affairs in progress, while FORTUNE praises the great performance of the age of machinery production. "Ballet dancer Luce embraces the art of communications and control," Marshall McLuhan commented [1]. The idea concept of "news magazine" initiated by Luce is very popular among the middle class. His idea of journal editing has attracted a large number of fans. Biographer Brinkley believed that the building of Luce's publishing empire is a microcosm of America in the middle $20^{\text {th }}$ century, when national mass culture emerged and served the booming middle class.

This paper, focusing on the journal editing model of Henry Luce, analyzes his journalistic thought and editing idea. Luce's idea of journal editing is still inspiring the late-comers. Journal founders must have their own idea and pursuit of journal in order to make success. Meanwhile, the background of era development and readers' mental demand should also be taken into account in order to form unique contents and viewpoints. 


\section{Original Model of "Newsweekly"}

Luce is a pathfinder of modern newsweekly. Originally, he wanted to create a new journal mode and have all major news from all newspapers and periodicals scattered on the reader's floor contained in a dozen-page magazine, which could save the time for busy people. In 1923, he founded TIME. He and his partner Harden was trying to make TIME a practical news digest when they were in Yale. They attempted to provide busy people with efficient and in-depth global news reports in a simple, readable and organized way, which influenced the design of both the journal title and format. To achieve this goal, they edited news of the week and reinforced them with comments, biographies and backgrounds for readers to analyze and interpret. Just as the commitment made by TIME, it informs readers of the current situation and saves their valuable time [2].

The journal editing idea was edge-leading in 1920s. Although Luce never had any systematic market research, he intuitively felt the most important social change, the accelerated living tempo and the localized business of that time. He realized that middle class needed to know further about the national and international affairs. Constrained by the increased occupational pressure and longer working time, they didn't have enough time to know things beyond their work and life. Luce read the mind of most Americans, i.e., they longed for a periodical that distinguishes and collates the most important era information for them.

The reporting style of newsweekly, different from the objective reporting of American newspapers, developed to an interpretative reporting style popular in the 1930s of America. Interpretative reporting is a kind of news report which applies background materials to analyze the cause, meaning, effect, or the development trend of a news event. It focuses on interpreting all the ins and outs of the news fact, elaborating their causes, results, and the relations among relevant events. Therefore, Luce proposed the famous theory of "fast news and slow news". Fast news is mainly characterized by the timeliness and objectiveness of news report, while slow news, although limited in timeliness, should be more profound and explanatory. TIME, as a newsweekly, provides readers with slow news. With concerns over major social problems, it rearranges news happening within a week and illustrates them with background material and in-depth analysis so that readers can have an in-depth and allrounded understanding of news events. The mode of newsweekly, favored by the upper class, had attracted lots of followers. Right after the $1^{\text {st }}$ anniversary of TIME in 1922, Reader's Digest was founded. It also focused on readers without time or willingness to read extensively and deeply. TIME expanded rapidly under the guidance of the idea of newsweekly, suggesting that the emerging middle class of America had an increasingly urgent demand for information and knowledge-based digest and that they had turned their interest from local community to the whole country.

\section{Industrialized Mode of News Production}

As the pioneer of newsweekly, TIME was edge-leading in multiple ways and created lots of operation modes widely referred to afterwards, e.g., the "group journalism”. News became a corporate work of reporters, researchers, chief writers and fact-checkers, which, with human interest, was similar to Hollywood comedies. This news production mode enabled magazines to respond immediately to breaking news. As on an industrial assembly line, efforts of a team were combined to finish a report. The cooperative news production mode had also been questioned by many insiders against the news personalization, authenticity and objectivity. Commented by Marshall McLuhan in The Mechanical Bride Folklore of Industrial Man, “TIME never provides readers with views and idea of news comments. On the contrary, the news is accompanied by Spike Jonze's boisterous revel, while politics, people and events are compressed into music. In TIME, the mission of trombone and trumpet is stories of the comment tribe” [3].

Nevertheless, newsweekly, the original media initiated by Luce, was widely praised by the public for its rich content and promptness. In the next few years, he founded some more magazines, including FORTUEN (1930), LIFE (1936) and SPORTS (1954). LIFE was the first magazine focusing on news and picture reporting. Luce had actually practiced the "editor-dominated system" he preaches. He always imposed the individual will on news report. As the chief editor of all magazines, he owned the ultimate executive power of all news reports, while journalists were just asked to provide background material for event observations and viewpoints. In the journal editorial office of TIME, the chief editor dominated ordinary editors, editors dominated writers and writers dominated journalists. The whole magazine became a propaganda machine of the news thought of Luce.

The talent utilization system employed by Luce was distinctive too. The first employees of TIME were top students from universities as Harvard and Yale rather than the press circles. Hardly anyone of composers of 
FORTUNE had any commercial or news experience. As Luce said, "It's easier to change a poet to a business reporter than changing a bookkeeper to a writer.” The most brilliant journalists of America were more aggressive and creative because they didn't have any related experience. Luce gave them more freedom. For instance, Margaret Bock White was the first full-time employee of TIME INC. Lots of pictures taken by her for LIFE were classic.

\section{Positioning in Middle Class}

TIME became an influential newsweekly on American public opinion in 1940s. Luce was once called as the one of the world's most influential people, which was closely associated with the reader positioning. TIME referred modern middle class in its advertising brochure to "a younger generation used to nice and convenient things", which represented the culture and new consumerism of modern middle class.

After TIME was founded, Luce didn't expect any large circulation of it. He and his partners were determined to found a "high-quality" magazine focusing on elite readers - the busy professionals. The earliest subscribers of TIME were alumni of Ivy League, members of elite men's clubs and country clubs, board officers, buyers of Harvard Classics, social celebrities and listed people of Who's Who. It boasted that its early subscribers included famous bankers, industrialists and politicians. These readers were distinctively young and wealthy, which was essentially important to advertisers. According to an advertisement of TIME, "We succeeded because we hit the imagination and fancy of young senior executives, the most interesting class of America. They are physically young. What's more, they have young spirit and world outlook” [4]. Investigations about the several major magazines showed that, in the 1920s and the first few years of 1930s, TIME ranked first in the affluence level of subscribers.

Magazines founded by Luce were pitched at high-end market also because it was enthusiastic about reporting powerful people. The characteristic of TIME was its favor of influential people and the layout of "Cover Star" and "Person of the Year". Ever since the initial issue of TIME, it had a portrait of a male or female celebrity on its cover. The portraits were sketches or black-and-white photos at first and became colorful in 1929. In 1927, TIME began to choose a "Person of the Year" every month. To be a cover person of TIME was a high honor to many readers. Standard cover people were prominent figures, important public persons and respected people in secular sense, including politicians, business leaders, generals and celebrities in art, entertainment and sports circles. In the first fifty years, Stalin showed twelve times on the cover of TIME; Roosevelt, Churchill, Franco and Mussolini showed eight times; Hitler and Chiang Kai-shek showed seven and ten times respectively. Cover Story and Person of the Year became the signature characteristic of the magazine. The layout of TIME have been imitated by numerous American and overseas news magazines.

Although Luce was confronted with the Great Depression when he was founding FORTUNE in 1930, he was optimistic about the publishing. He insisted on making an amazing magazine. The printing cost was unbelievably high, and hence the selling price was as high as \$1. Compared with the price of five-cent or ten-cent of most magazines then, the price of FORTUNE was astonishingly high. But Luce had accurately predicted that the price would grant FORTUNE a status, which would attract the rich readers he targeted-“the active, smart and influential individuals who are decisive in the industry and commerce of America.”

\section{Advocacy of "American Century"}

Henry Luce was an extraordinary entrepreneur. He tried to advocate a view that was already implanted in Americans through his magazines, i.e., "the American Century". In Jan. 1940, Luce wrote an editorial for LIFE, We Americans, in which it was clearly proposed that America must cooperate with Britain to resist the German Nazis. But the editor refused to publish such an intentional article. A year later, Luce expanded the article and renamed it as "The American Century" and published it on LIFE. It explicated the point that "America is the most powerful and important country of the world today; meanwhile, it has got rid of the fear of Europe, which means America has the responsibility to reshape the world.” The greatly influential article urged Americans to intervene in the war and suggested that America must contribute to the establishment of a free and progressive economic order, take responsibility in international affairs, fight for justice and pursue freedom and truth. It also referred $20^{\text {th }}$ century as the American Century.

America began to export its mass culture after World War I. Jazz, Hollywood movies and American slangs and machines were transferred to all countries worldwide. Luce, with his unique professional sensibility, rea- 
lized that American mass culture was highly attractive to the external world. He strengthened this opinion in his magazines. Luce also tried to export and advocate American values ideologically to promote and welcome the arrival of the American Century. LIFE was always enthusiastic about introducing the living and dwelling condition of Middle America, describing American life and culture and building a contagious image of the middle class. "It is the most important part of American civilization," wrote fictionist William Brinkley in 1961.

Luce's proposition of "the American Century" was well received by the American government and many decision makers. It met the desire of America of being the world leader with all the power it had got. By this point, Luce was a successful entrepreneur. He successfully predicted the interest shift of American mass and social trends, based on which a series of media achievements were made.

\section{Conclusion}

To sum up, in the information era of today, audience has been further differentiated. It is impossible for any media to attract all middle-class readers and for any magazine to thrive as in the age of Luce. Luce's idea of journal editing is still inspiring the late-comers. Journal founders must have their own idea and pursuit of journal in order to make success. Meanwhile, the background of era development and readers' mental demand should also be taken into account in order to form unique contents and viewpoints.

\section{References}

[1] McLuhan, M. (He, D.K., Trans.) (2004) The Mechanical Bride Folklore of Industrial Man. China Renmin University Press, Beijing, 16.

[2] Brinkley, A. (Zhu, X.Y. and Ding, C.J., Trans.) (2011) The Publisher: Henry Luce and His American Century. Law Press, Beijing, 112.

[3] McLuhan, M. (He, D.K., Trans.) (2004) The Mechanical Bride Folklore of Industrial Man. China Renmin University Press, Beijing, 15.

[4] Brinkley, A. (Zhu, X.Y. and Ding, C.J., Trans.) (2011) The Publisher: Henry Luce and His American Century. Law Press, Beijing, 114-115. 